\title{
Leptin Affects Prolactin Action on Milk Protein and Fat Synthesis in the Bovine Mammary Gland
}

\author{
Y. Feuermann, ${ }^{1,2}$ S. J. Mabjeesh, ${ }^{2}$ and A. Shamay ${ }^{1}$ \\ ${ }^{1}$ Institute of Animal Science, Agricultural Research Organization, the Volcani Center, \\ P.O. Box 6, Bet Dagan 50250, Israel \\ ${ }^{2}$ Department of Animal Science, Faculty of Agriculture, Food and Environmental Quality Sciences, \\ The Hebrew University of Jerusalem, P.O. Box 12, Rehovot 76100, Israel
}

\begin{abstract}
Leptin, a protein hormone produced and secreted predominantly by white adipose tissue, has a critical role in the regulation and coordination of energy metabolism. Identification of leptin in the milk of several mammals, including humans, led us to investigate its presence and regulatory effect in the cow mammary gland. The expression of leptin receptor in tissue culture of lactating mammary gland was augmented approximately 25 times by prolactin, but had no effect on virgin calf mammary tissue. Expression of leptin in tissue culture from mammary glands of lactating cows was enhanced 2.2fold by prolactin. No effect of prolactin on leptin and leptin receptor expression was found in mammary gland tissue culture from calves. Leptin-enhanced fatty acid synthesis in the presence of prolactin, but had no effect without presence of prolactin. A similar pattern was found in the expression of $\alpha$-casein and $\beta$-lactoglobulin in mammary gland explants from a lactating cow. Our findings indicate that leptin plays an important role in mammary gland lactogenesis, and that the expression of leptin requires the presence of prolactin.
\end{abstract}

(Key words: bovine mammary gland, leptin, prolactin, fat synthesis)

Abbreviation key: Ob-Ra = short isoform of the leptin receptor, $\mathbf{O b}-\mathbf{R b}=$ long isoform of the leptin receptor, rt-RT-PCR $=$ real-time, reverse transcription-PCR.

\section{INTRODUCTION}

Fate of the mammary gland is controlled by cellular processes that are under the control of steroid and peptide hormones (Topper and Freeman, 1980). Growth and limited differentiation occurs during puberty and requires action of hormones such as estrogen and prolactin. The mammary fat pad was once considered as

Received October 23, 2003.

Accepted March 26, 2004.

Corresponding author: A. Shamay; e-mail: Shamay@agri.huji. ac.il. an inert matrix, but more recent evidence indicates that the adipocyte-epithelial interaction is critical for mammary duct growth and morphogenesis (Zangani et al., 1999). Locally produced growth factors are believed to mediate the adipocyte-epithelial interactions and to alter actions of several steroid and peptide hormones in these tissues (Hovey et al., 1999). Prolactin, a hormone secreted from the pituitary acidophil cells has an important role in the morphological and biochemical differentiation of the epithelial cells during pregnancy, and regulates milk protein synthesis during lactation (Groner, 2002). Basal concentrations of prolactin increase throughout the course of pregnancy, up to 10 -fold by term, and remains elevated during the postpartum period (Conn and Melmed, 1997). It was recently reported that mammary adipocytes expressed leptin during early stages of development in sheep (Bonnet et al., 2002). Leptin, a protein hormone secreted predominantly by white adipose tissue (Friedman and Halaas, 1998), plays a critical role in regulating and coordinating energy metabolism; it regulates the metabolism of key tissues involved in the storage and dissipation of energy (Banks et al., 2000). Therefore, leptin may be important in regulating metabolic adaptation of nutrient partitioning during the energy-consuming processes of pregnancy and lactation (Moschos et al., 2002). Although white adipose tissue is the main site of leptin production, the leptin gene is also expressed in placental and fetal tissues, the mammary glands, the stomach, muscles, brown adipose tissue, etc. (Andrews, 1998). Thus, leptin as a lipolytic factor may increase peripheral use or oxidation of fatty acids, and enhance glucose uptake (Kamohara et al., 1997; Schneider and Zhou, 1999). Leptin has been found in sheep mammary adipocytes during early pregnancy and in mammary epithelial cells during lactation (Bonnet et al., 2002). In contrast, leptin receptor mRNA was found in epithelial cells in the ovine mammary gland (Laud et al., 1999) and in the bovine epithelial MAC-T cells (Silva et al., 2002). The leptin receptor (Ob-R) is a member of the class I cytokine receptor family and is present in 5 differently spliced forms: Ob-Ra, Ob-Rb, Ob-Rc, Ob-Rd, 
and Ob-Re (Tartaglia et al., 1995). The long isoform of the receptor $(\mathbf{O b}-\mathbf{R b})$ is predominantly expressed in the hypothalamus and is essential for weight-reducing effects of leptin. Other isoforms lack some or all of the intracellular domains of Ob- $\mathrm{Rb}$ (Friedman and Halaas, 1998). The short form of the leptin receptor (Ob-Ra) is expressed in many different tissues in mice (Bjorbaek et al., 1997) and cattle (Chelikani et al., 2003), and is capable of leptin-mediated signaling. However, physiological significance of Ob-Ra signaling is not known. In cattle, tissue distribution of leptin receptor isoforms is not well established, and expression of Ob-Ra in cattle has been reported previously only for the adrenal gland (Yanagihara et al., 2000) pituitary, liver, and spleen (Chelikani et al., 2003). Expression of Ob-Ra in the bovine mammary gland during lactation has not been established, although its presence in the lactating ovine mammary gland has been (Laud et al., 1999).

The objective of the present study was to determine the effect of leptin on various traits of milk synthesis in the bovine mammary gland and define its interaction with prolactin.

\section{MATERIALS AND METHODS}

\section{Animals}

Mammary tissue was obtained from Holstein cows at a local abattoir. For the fat synthesis experiments, mammary tissue was obtained from 5 cows, 2 to 5 mo after onset of lactation. For the rt-RT-PCR experiments of leptin and its receptor expression, mammary tissue was obtained from 4 10- to 14-mo-old postpubertal calves and 4 cows, 2 to 5 mo after onset of lactation. For real-time, reverse transcription-PCR (rt-RT-PCR) experiments of $\alpha$-CN and $\beta$-LG expression, 3 cows were used.

\section{Materials}

M-199, penicillin, streptomycin, and Fungizone (amphotericin B) were obtained from Bet Haemek, Israel. Bovine insulin, cortisol, and ovine prolactin were purchased from Sigma (St. Louis, MO). Bovine recombinant leptin was a gift from A. Gertler. Acetate $\left({ }^{14} \mathrm{C}\right.$ labeled) was purchased from Amersham Pharmacia Biotech (Buckinghamshire, UK).

\section{Explants Culture}

Mammary tissue obtained from cows and calves at a local abattoir was transferred into medium M-199 containing $100 \mathrm{U}$ of penicillin, $100 \mu \mathrm{g}$ of streptomycin, $0.25 \mu \mathrm{g}$ of Fungizone, and insulin at $1 \mu \mathrm{g} / \mathrm{mL}$. Explants were prepared as previously described (Shamay et al.,
1987). Twenty explants (50 to $80 \mathrm{mg}$ total weight) were placed on an impregnated lens paper floating in $5 \mathrm{~mL}$ of M-199 medium, and were cultured at $37^{\circ} \mathrm{C}$ in medium supplemented with insulin (I) at $1 \mu \mathrm{g} / \mathrm{mL}$, cortisol (F) at $0.5 \mu \mathrm{g} / \mathrm{mL}$, and prolactin $(\mathrm{P})$ at various concentrations (IFP); and medium supplemented only with insulin at $1 \mu \mathrm{g} / \mathrm{mL}$ and cortisol at $0.5 \mu \mathrm{g} / \mathrm{mL}$ (IF). Leptin was added according to the experimental protocol. Medium was changed every $24 \mathrm{~h}$ during $5 \mathrm{~d}$.

\section{Fat Synthesis}

Fat synthesis was determined by the incorporation of $\mathrm{CH}_{3}{ }^{14} \mathrm{COOH}(0.2 \mu \mathrm{Ci} / \mathrm{mL})$ into fatty acids, as previously described (Gertler et al., 1983).

\section{Isolation of RNA}

Total RNA was isolated from the mammary tissue explants by the acid guanidinium thiocyanate phenolchloroform extraction method (Chomczynski and Sacchi, 1987). Upon isolation, RNA was frozen at $-70^{\circ} \mathrm{C}$ pending analysis by the reverse transcription-polymerase chain reaction (RT-PCR) or real time PCR (rt-PCR).

\section{Reverse Transcription}

Two micrograms of total RNA was reverse transcribed in a final volume of $20 \mu \mathrm{L}$ of $50 \mathrm{~m} M$ Tris- $\mathrm{HCl}(\mathrm{pH}$ 8.3), $75 \mathrm{~m} M \mathrm{KCl}, 5 \mathrm{~m} M \mathrm{MgCl}_{2}, 10 \mathrm{~m} M$ dithiothreitol, 0.5 $\mathrm{m} M$ deoxy-NTP (dNTP), $0.5 \mu \mathrm{g}$ of oligo dT/Hexamer primers (Promega, Madison, WI), and $1 \mathrm{U}$ of avian myeloblastosis virus (AMV) reverse transcriptase (Promega). Reaction temperatures were $42^{\circ} \mathrm{C}$ for $1 \mathrm{~h}$ and $95^{\circ} \mathrm{C}$ for $10 \mathrm{~min}$.

\section{Real-Time-PCR}

Samples of RNA were reverse transcribed as described above. Samples were analyzed by real-time PCR with the ABI Prism 7000 system (Applied Biosystems, Foster City, CA). A 5- $\mu \mathrm{L}$ sample of cDNA was amplified for 40 cycles with $3 \mu \mathrm{L}$ of the following primers at a final concentration of $20 \mu M$ : leptin primers (sense 5'GGA GAA GGT CCC GGA GGT T-3' , antisense 5'-GGA CCA GAC ATT GGC GAT CT-3'), $\beta$-lactoglobulin primers (sense 5'-ATC CCT GCG GTG TTC AAG AT-3', antisense $5^{\prime}$-CCA TGC AGA CGA GCA GGT ACT $-3^{\prime}$ ), $\alpha$-CN primers (sense $5^{\prime}$-TCT GCA CCT TCC TCT GCC TC -3', antisense 5'-AAA GGG ACA GCA CGG ACT GA $-3^{\prime}$ ), leptin receptor primers (sense 5'-AGC GCG GAA GAT AAA AAC TGC - $3^{\prime}$, antisense 5'-TTT GCA CCT GTT TGC TGA AAA-3'). As normalizing controls, bovine ribosomal $18 \mathrm{~S}$ primers (sense 5'-CGG CTA CCA 
CAT CCA AGG AA-3', antisense 5'- GGG CCT CGA AAG AGT CCT GT $-3^{\prime}$ ) were used. The reaction was carried out in a final volume of $50 \mu \mathrm{L}: 16 \mu \mathrm{L}$ of SYBR Green (Applied Biosystems), $3 \mu \mathrm{L}$ of $5 \mu M$ primers mix, $3 \mu \mathrm{L}$ of $5 \mu M$ reverse primer, $5 \mu \mathrm{L}$ of template (cDNA), and $23 \mu \mathrm{L}$ of deionized water, for 40 cycles of $1 \mathrm{~min}$ of denaturation at $95^{\circ} \mathrm{C}, 2 \mathrm{~min}$ of annealing at $60^{\circ} \mathrm{C}$, and 1 min of extension at $72^{\circ} \mathrm{C}$. The amplified PCR product was analyzed by means of ABI Prism 7000 software (Applied Biosystems). At the end of the rt-PCR run, a melting curve was performed to verify the presence of a single amplicon.

\section{Analysis of rt-PCR}

Real-time PCR analysis was performed by the ${ }^{\Delta \Delta} \mathrm{CT}$ method (Applied Biosystems). The CT stands for the threshold cycle (i.e., the PCR cycle in which an increase in reporter fluorescence above a baseline signal can first be detected). The proportional change detected in mRNA is calculated as $2^{-\Delta \Delta \mathrm{CT} \text {; }}$

$$
\begin{gathered}
{ }^{\Delta \Delta} \mathrm{CT}= \\
\left(\mathrm{CT}_{\text {assayed gene:treated }}-\mathrm{CT}_{18 \text { s:treated }}\right) \\
-\left(\mathrm{CT}_{\text {assayed gene:control }}-\mathrm{CT}_{18 \mathrm{~s}: \text { control }}\right),
\end{gathered}
$$

where subscripts refer to mRNA amplified gene and whether the sample was treated or control.

\section{Statistical Analyses}

Fatty acid synthesis data of lactating cows and calves were analyzed as a $2 \times 3$ factorial experiment by ANOVA using the GLM procedure of SAS (2001). Treatments included 2 doses of prolactin $(0$ and $1 \mu \mathrm{g} / \mathrm{mL})$ and 3 doses of leptin $(0,10$, and $100 \mathrm{ng} / \mathrm{mL})$. The statistical model included the main effects leptin (3 doses), and prolactin ( 2 doses) in the medium, and their interactions. When significant $F$-tests were detected, least square means were compared using Student's $t$-test.

Statistical analysis of the rt-PCR of the leptin and leptin receptor expression in calves and lactating cows was performed as described by Livake and Schmittgen (2001).

Data from the rt-PCR experiments for the expression of $\beta$-LA and $\alpha$-CN in lactating cows were analyzed as described previously for the fatty acid synthesis, except data were transformed to logarithmic scale of base 2 before analysis. Results from this experiment are presented as the antilogarithmic form of the least square means.
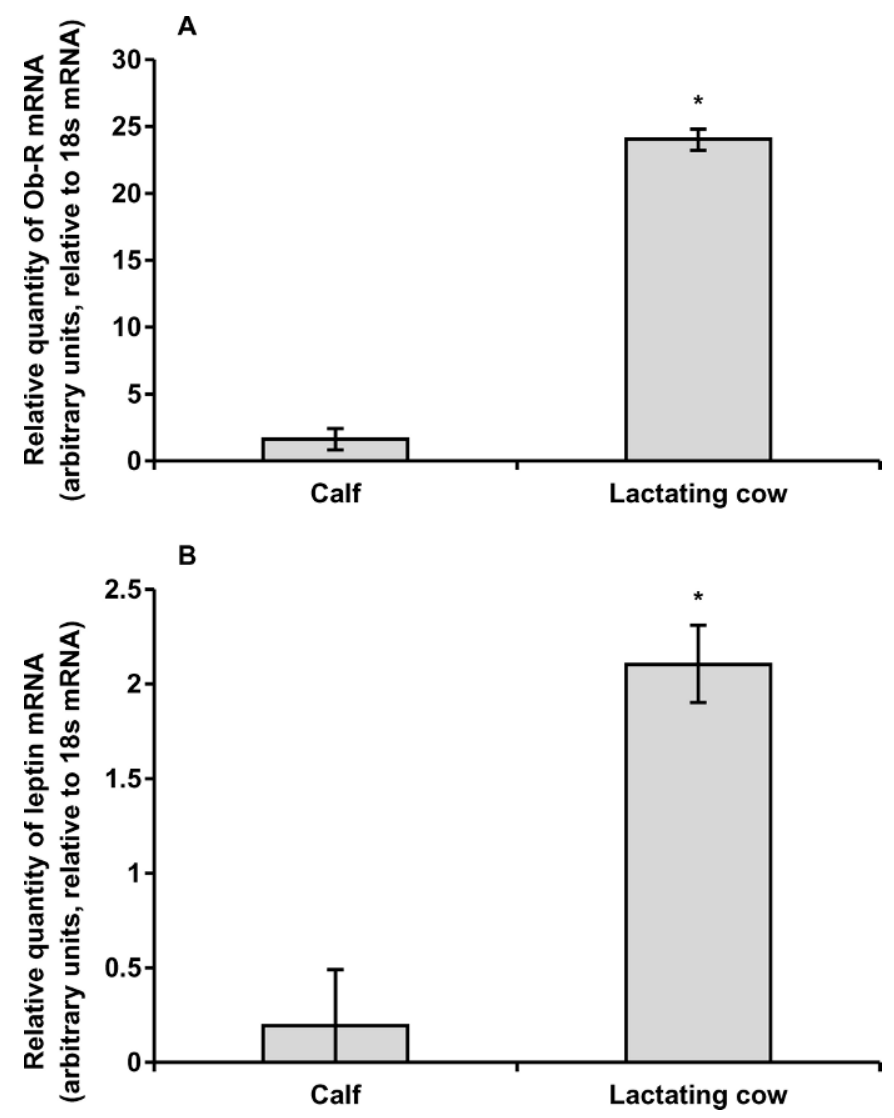

Figure 1. Expression of leptin receptor Ob-R (a) and leptin (b) mRNA in mammary gland explants from lactating cows and calves. Explants were incubated with insulin (I) and cortisol (F; IF) or with insulin (I), cortisol (F) and prolactin (P) (IFP) for $4 \mathrm{~d}$. Expression of leptin and leptin receptor in the explants was measured by real-time PCR after $4 \mathrm{~d}$ in culture. Results are least square means $\pm \mathrm{SE}$ of 4 independent experiments for cows $(\mathrm{n}=4)$ and calves $(\mathrm{n}=4)$. *Means that differed $(P<0.05)$ from the base line (IF treatment) are labeled.

\section{RESULTS}

\section{Leptin and Leptin Receptor Expression}

Mammary gland explants from lactating cows and calves were incubated for $4 \mathrm{~d}$ in medium with or without prolactin (at $1 \mu \mathrm{g} / \mathrm{mL}$ ). Expression of leptin receptor in mammary gland tissue from lactating cows was enhanced approximately 25 times by prolactin (Figure 1a). Expression of leptin was enhanced 2.2 fold by $1 \mu \mathrm{g} /$ $\mathrm{mL}$ prolactin (Figure 1b) when analyzed by rt-PCR. Prolactin had no effect on leptin receptor expression in virgin calf mammary gland tissue. No effect of prolactin on leptin expression was found in virgin calf mammary gland tissue.

\section{Fatty Acid Synthesis in Explants}

Mammary gland explants from lactating cows were incubated for $4 \mathrm{~d}$ in medium containing $1 \mu \mathrm{g} / \mathrm{mL}$ prolac- 


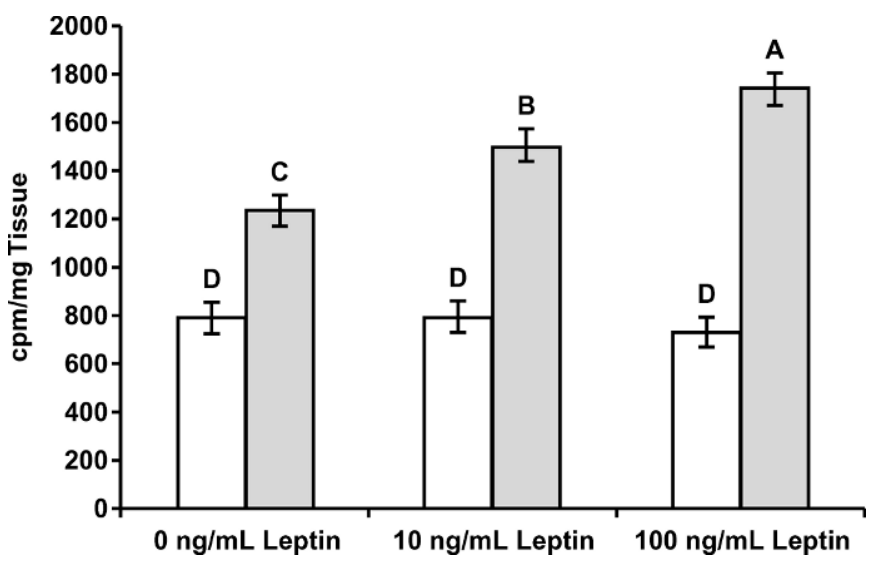

Figure 2. Effect of leptin and prolactin on fatty acid synthesis in explants from mammary gland of lactating cows. Fatty acid synthesis was measured after $4 \mathrm{~d}$ in culture in the presence of 3 doses of leptin with (filled bars) or without prolactin (open bars). Least square means $\pm \mathrm{SE}(\mathrm{n}=5)$ for the interaction $(P<0.02)$ of main effects of prolactin and leptin on fatty acid synthesis are illustrated (SEM $=68.1$ ). Bars with different letters differ $(P<0.05)$.

tin (IFP) or without prolactin (IF), and 3 different doses of leptin $(0,10$, and $100 \mathrm{ng} / \mathrm{mL})$. As shown in Figure 2, addition of prolactin to the medium elevated the level of fatty acid synthesis in explants compared with the level in explants incubated without prolactin. Addition of leptin to medium without prolactin did not affect the fatty acid synthesis at any level of leptin concentration. On the other hand, addition of leptin to medium containing prolactin at $1 \mu \mathrm{g} / \mathrm{mL}$ enhanced the fatty acid synthesis in the mammary explants with leptin at 10 and $100 \mathrm{ng} / \mathrm{mL}$.

\section{Expression of $\alpha$-CN and $\beta$-LG mRNA}

Mammary gland explants from lactating cows were incubated for $4 \mathrm{~d}$ in medium with or without prolactin (at $1 \mu \mathrm{g} / \mathrm{mL}$ ) and 3 different doses of leptin $(0,10$, and $100 \mathrm{ng} / \mathrm{mL}$ ). Expression of $\beta$-LG gene was elevated threefold by prolactin, and the addition of leptin to medium containing prolactin augmented the expression sixteenfold. Leptin had no effect on $\beta$-LG expression in mammary gland explants cultured in medium without prolactin (Figure 3a). The same trend was found in the expression of $\alpha$-CN under the same hormonal treatments (Figure $3 \mathrm{~b}$ ).

\section{DISCUSSION}

We report here the first evidence that prolactin enhanced leptin receptor expression in the mammary gland of lactating cows, but did not affect that in virgin calves. This finding implies that leptin might play an important role in the distribution of nutrients and en-
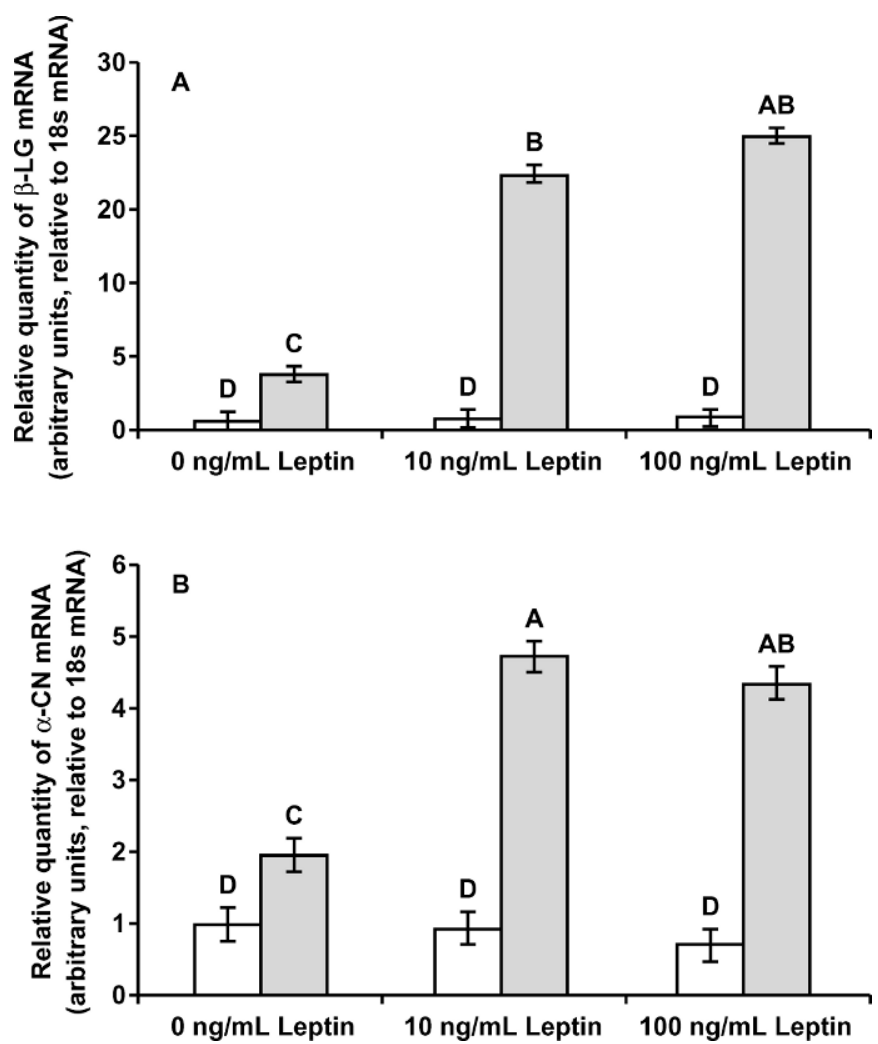

Figure 3. Effects of leptin and prolactin on $\beta$-LG (a) and $\alpha$-CN (b) mRNA expression in mammary gland explants of lactating cows. Expression of $\beta$-LG and $\alpha$-CN was measured by real-time PCR after incubation with 3 doses of leptin $(0,10$, and $100 \mathrm{ng} / \mathrm{mL})$, with prolactin (filled bars) or without prolactin (open bars). Least square means \pm $\mathrm{SE}$ for the interactions of main effects of leptin and prolactin on $\beta$ LG expression $(\mathrm{n}=3$; SEM $=1.62 ; P<0.05)$ on $\alpha$-CN expression $(\mathrm{n}=$ 3 ; $\mathrm{SEM}=1.17 ; P<0.01)$ are illustrated. Bars with different letters differ $(P<0.05)$.

ergy in the mammary gland during lactation. Expression of leptin receptor mRNA in the mammary gland was previously reported in sheep (Laud et al., 1999), mice (Aoki et al., 1999), and humans (Smith-Kirwin, et al., 1998). The amount of leptin receptor expression in the ovine mammary gland was greatest during midpregnancy (Laud et al., 1999). The abundant expression of the leptin receptor transcript within the mammary epithelial cells at midpregnancy (Laud et al., 1999) coincides with the initiation of mammary epithelial cell proliferation, which occurs as growth of the mammary gland begins in the ewe (Houdebine, 1985). We report here that prolactin enhanced leptin gene expression in the bovine mammary gland. Bovine mammary gland expressed leptin mRNA similarly to mammary gland tissues of humans (Smith-Kirwin et al., 1998) and mice (Aoki et al., 1999), and the MAC-T cell line (Smith and Sheffield, 2002). Prolactin affected leptin mRNA expression in bovine mammary gland tissue only in 
lactating cows and not in virgin calves. This result, together with the finding that leptin-deficient mice induced to become pregnant delivered normally, but failed to lactate (Mounzih et al., 1998), supports the hypothesis that leptin plays an important role in the mammary gland when lactogenic metabolism is initiated. The fact that they could not induce lactation with exogenous human recombinant leptin supports our hypothesis that leptin acts as an autocrine factor in the mammary gland.

We report here that leptin in the presence of prolactin, enhanced fatty acid synthesis and elevated the expression of $\alpha$-CN and $\beta$-LG gene, but had no effect on fatty acid, $\alpha-\mathrm{CN}$, and $\beta$-LG synthesis in the absence of prolactin. Our findings disagree with those of Baratta et al. (2003), who found that leptin seemed to exert a positive influence on milk protein induction in the mammary epithelium HC11 cell line, with or without classical lactogenic hormones such as prolactin and insulin. We suggest that leptin affects milk protein expression and fat synthesis in the bovine mammary gland in the presence of prolactin. Silva et al. (2002) found that leptin influenced DNA synthesis in MAC-T cells. Further, it decreased DNA synthesis in these cells after stimulation of cell growth with fetal bovine serum or with IGF-I, whereas leptin alone had no effect on cell proliferation. Silva et al. (2002) also found that leptin inhibited cell metabolism in the presence of growth factors, whereas we have found that it stimulated mammary gland metabolism in the presence of prolactin. This difference can be explained by the fact that they found Ob-Rb in MAC-T cells and in isolated mammary epithelial cells of prepubertal heifers, but did not detect expression of Ob-Ra in either source of bovine mammary tissue. In contrast, mammary gland of sheep expresses $\mathrm{Ob}-\mathrm{Ra}$ and $\mathrm{Ob}-\mathrm{Rb}$ during pregnancy and lactation (Laud et al., 1999). In the bovine mammary gland, expression of Ob-Rb was established (Silva et al., 2002), but not that of Ob-Ra. Primers for leptin receptor used in these experiments do not distinguish between the long and short leptin receptors.

Our finding that expression of leptin and leptin receptor in virgin mammary gland did not change in the presence of prolactin strengthens our hypothesis that leptin and the leptin receptor can interact with lactogenic hormones only after the mammary gland has reached a mature stage of development. This hypothesis is based on the fact that expression of the leptin receptor changes through stages of the mammary gland development. In a previous study (unpublished data), we found that expression of leptin receptor was high in mammary tissue of a mature heifer, maintained during pregnancy, and declined in the lactating cow. Expression was greater in cows at all stages than in calves.
In light of this study, together with findings of Laud et al. (1999), we suggest that the leptin receptor is strongly expressed at stages of massive development of the mammary gland.

The results of the present study demonstrate that prolactin can regulate leptin and leptin receptor gene expression and may interact with leptin during lactation to alter milk synthesis. Leptin may play an important role, as a metabolic factor, in the distribution of nutrients and in energy partitioning in the mammary gland during lactation, but it needs the presence of prolactin.

\section{ACKNOWLEDGMENTS}

We thank A. Gertler for the gift of bovine recombinant leptin, G. Brener, D. Hochman, and A. Tomer for their help at the Marbek Co. abattoir, and the Cattle Breeders' Association of Israel for its support.

\section{REFERENCES}

Andrews, J. F. 1998. Leptin: Energy regulation and beyond to a hormone with pan-physiological function. Proc. Nutr. Soc. 57:409-411.

Aoki, N., M. Kawamura, and T. Matsuda. 1999. Lactation-dependent down regulation of leptin production in mouse mammary gland. Biochim. Biophys. Acta 1427:298-306.

Banks, A. S., S. M. Davis, S. H. Bates, and M. G. Myers, Jr. 2000. Activation of downstream signals by the long form of the leptin receptor. J. Biol. Chem. 275:14563-14572.

Baratta, M., S. Grolli, and C. Tamanini. 2003. Effect of leptin in proliferating and differentiated HC11 mouse mammary cells. Regul. Pept. 113:101-107.

Bjorbaek, C., S. Uotani, B. da Silva, and J. S. Flier. 1997. Divergent signaling capacities of the long and short isoforms of the leptin receptor. J. Biol. Chem. 272:32686-32695.

Bonnet, M., I. Gourdou, C. Leroux, Y. Chilliard, and J. Djiane. 2002. Leptin expression in the ovine mammary gland: Putative sequential involvement of adipose, epithelial, and myoepithelial cells during pregnancy and lactation. J. Anim. Sci. 80:723-728.

Chelikani, P. K., D. R. Glimm, and J. J. Kennelly. 2003. Short Communication: Tissue distribution of leptin and leptin receptor mRNA in the bovine. J. Dairy Sci. 86:2369-2372.

Chomczynski, P., and N. Sacchi. 1987. Single-step method of RNA isolation by acid guanidinium thiocyanate-phenol-chloroform extraction. Anal. Biochem. 162:156-159.

Conn, M. P., and S. Melmed, eds. 1997. Endocrinology: Basic and clinical principles. Humana Press, Totowa, NJ.

Friedman, J. M., and J. L. Halaas. 1998. Leptin and the regulation of body weight in mammals. Nature 395:763-770.

Gertler, A., N. Cohen, and A. Maoz. 1983. Human growth hormone but not ovine or bovine growth hormones exhibits galactopoietic prolactin-like activity in organ culture from bovine lactating mammary gland. Mol. Cell. Endocrinol. 33:169-182.

Groner, B. 2002. Transcription factor regulation in mammary epithelial cells. Domest. Anim. Endocrinol. 23:25-32.

Houdebine, L. M. 1985. Hormonal regulation of the normal mammary gland. Bull. Cancer 72:121-141.

Hovey, R. C., T. B. McFadden, and R. M. Akers. 1999. Regulation of mammary gland growth and morphogenesis by the mammary fat pad: A species comparison. J. Mammary Gland Biol. Neoplasia 4:53-68.

Kamohara, S., R. Burcelin, J. L. Halaas, J. M. Friedman, and M. J. Charron. 1997. Acute stimulation of glucose metabolism in mice by leptin treatment. Nature 389:374-377. 
Laud, K., I. Gourdou, L. Belair, D. H. Keisler, and J. Djiane. 1999. Detection and regulation of leptin receptor mRNA in ovine mammary epithelial cells during pregnancy and lactation. FEBS Lett. 463:194-198.

Livak, K. J., and T. D. Schmittgen. 2001. Analysis of relative gene expression data using real-time quantitative PCR and the 2(Delta Delta C(T)) Method. Methods 25:402-408.

Moschos, S., J. L. Chan, and C. S. Mantzoros. 2002. Leptin and reproduction: A review. Fertil. Steril. 77:433-444.

Mounzih, K., J. Qiu, A. Ewart-Toland, and F. F. Chehab. 1998. Leptin is not necessary for gestation and parturition but regulates maternal nutrition via a leptin resistance state. Endocrinology 139:5259-5262.

SAS User's Guide: Statistics, Release 8.2, 2001. SAS Inst., Inc., Cary, NC.

Schneider, J. E., and D. Zhou. 1999. Interactive effects of central leptin and peripheral fuel oxidation on estrous cyclicity. Am. J. Physiol. Regul. Integr. Comp. Physiol. 277:R1020-1024.

Shamay, A., E. Zeelon, Z. Ghez, N. Cohen, A. G. Mackinlay, and A. Gertler. 1987. Inhibition of casein and fat synthesis and alphalactalbumin secretion by progesterone in explants from bovine lactating mammary glands. J. Endocrinol. 113:81-88.
Silva, L. F., M. J. VandeHaar, M. S. Weber Nielsen, and G. W. Smith. 2002. Evidence for a local effect of leptin in bovine mammary gland. J. Dairy Sci. 85:3277-3286.

Smith, J. L., and L. G. Sheffield. 2002. Production and regulation of leptin in bovine mammary epithelial cells. Domest. Anim. Endocrinol. 22:145-154.

Smith-Kirwin, S. M., D. M. O'Connor, J. De Johnston, E. D. Lancey, S. G. Hassink, and V. L. Funanage. 1998. Leptin expression in human mammary epithelial cells and breast milk. J. Clin. Endocrinol. Metab. 83:1810-1813.

Tartaglia, L. A., M. Dembski, X. Weng, N. Deng, J. Culpepper, R. Devos, G. J. Richards, L. A. Campfield, F. T. Clark, J. Deeds, and et al. 1995. Identification and expression cloning of a leptin receptor, OB-R. Cell 83:1263-1271.

Topper, Y. J., and C. S. Freeman. 1980. Multiple hormone interactions in the developmental biology of the mammary gland. Physiol. Rev. 60:1049-1106.

Yanagihara, N., K. Utsunomiya, T. B. Cheah, H. Hirano, K. Kajiwara, K. Hara, E. I. Nakamura, Y. Toyohira, Y. Uezono, S. Ueno, and F. Izumi. 2000. Characterization and functional role of leptin receptor in bovine adrenal medullary cells. Biochem. Pharmacol. 59:1141-1145.

Zangani, D., K. M. Darcy, S. Shoemaker, and M. M. Ip. 1999. Adipocyte-epithelial interactions regulate the in vitro development of normal mammary epithelial cells. Exp. Cell Res. 247:399-409. 